\title{
MLL/SH3GL1 Fusion Protein
}

National Cancer Institute

\section{Source}

National Cancer Institute. MLL/SH3GL1 Fusion Protein. NCI Thesaurus. Code C99506.

A fusion protein encoded by the MLL/SH3GL1 fusion gene. This protein is comprised of the $\mathrm{N}$-terminal half of the histone-lysine N-methyltransferase MLL protein, including the AT hook DNA binding domain and the DNA methyltransferase domain, fused to most of the endophilin-A2 protein. 